\title{
SOME NOTES OF THE HYDROGRAPHIC SURVEYS IN INDONESIAN WATERS
}

\author{
by \\ DJAMHIR PARDJAMAN ${ }^{1)}$
}

\begin{abstract}
During the period of 1969 to 1975 "JANHIDROS" carried out several hydrographic surveys and marine investigations in the Sunda Shelf and its adjacent waters. Data obtained during these surveys has shown that the general characteristics of the area which are primarily governed by the monsoonal regime are also affected by local conditions. The purpose of this paper is to render data based on these surveys which may be useful to complement environmental information.
\end{abstract}

\section{INTRODUCTION}

Hydrography is the science dealing with the study and description of all the waters covering the earth surface. Since the word means "description of water" hydrography might be taken to include matters of interest in the fields of oceanography, hydrology, maritime meteorology, and geography.

Hydrography is also that branch of surveying dealing with these matters, including the construction of charts demonstrating shoals, channels, coastlines, aids to navigation, landmarks, tides, currents, and topographic features of the ocean floor. The division within "JANHIDROS" concerned with these activities is the technical division which consists of the following sections:

1. Hydrographic Section dealing with hydrographic surveys mainly in coastal waters.

2. Oceanographic Section

- dealing with oceanographic investigations mainly to support hydrographic and other off shore activities.

3. Maritime Meteorologic Section

- dealing with meteorologic observation and climatology.

4. Maritime Geographic Section

- dealing with compilation of data about near shore areas.

1) Chief of the Hydro-Oceanographic Service, Jakarta. 


\section{DJAMHIR PARDJAMAN}

Hydrographic surveys in the Sunda Shelf and adjacent waters during the past six years, mainly for harbour engineering and promoting the safety of navigation were conducted among others in the following areas:

Dumai, Belawan, Rupat, Tg. Priok, Surabaya, Indramayu, Cirebon, West Kalimantan, Jambi \& Musi, Bali and the Malacca Straits.

Other research activities in above mentioned area include hydrology, maritime meteorology, geography, biology and geology.

For these activities, "JANHIDROS" operates four ships, namely:
1. KRI BURUJULASAD
1.800 ton
2. KRI JALANIDHI
750 ton
3. KRI BURJAMHAL
1.200 ton
4. KRI ARIES
50 ton

In addition several motor launches were used in shallow waters.

\section{GENERAL DESCRIPTION}

The area described in the present paper forms a part of the so called "Sunda Shelf" which is an extension of the South East Asia Continent that connects the mainland with the islands of Kalimantan, Sumatera and Jawa. This shelf supports the southern half of the South China Sea, the Gulf of Thailand and the Jawa Sea until the Makassar Strait. The whole area lies on a partly submerged land bridge, joining the Asian and the Australian Continents.

It is found that nowhere in this area depths exceed $183 \mathrm{~m}$ (100 fathoms), as may be seen in Figure 1 . The $185 \mathrm{~m}$ depth line extends from the South China Sea in south westerly direction to its extremity at latitude $10^{\circ} \mathrm{N}$ and longitude $112^{\circ} \mathrm{E}$. A shallow region, with depth of less than $55 \mathrm{~m}$ (30 fathom) is found extending southward from the South China Sea through the Gaspar and Karimata Straits and further westward.

The climate of the area is governed by the North West-monsoon and the South East-monsoon, resulting in fair and regular climatic variations. The two air streams, flowing in opposite directions, cause appreciable variations in temperature, precipitation, visibility, cloudiness, and humidity.

The severe tropical storms which often occur in the north and south of the Indonesian waters during the period of late summer on both hemisphere are called "typhoons" (north of Indonesia) and "cyclqne and willy-willies" (south of Indonesia). 
SOME NOTES OF THE HYDROGRAPHIC SURVEYS

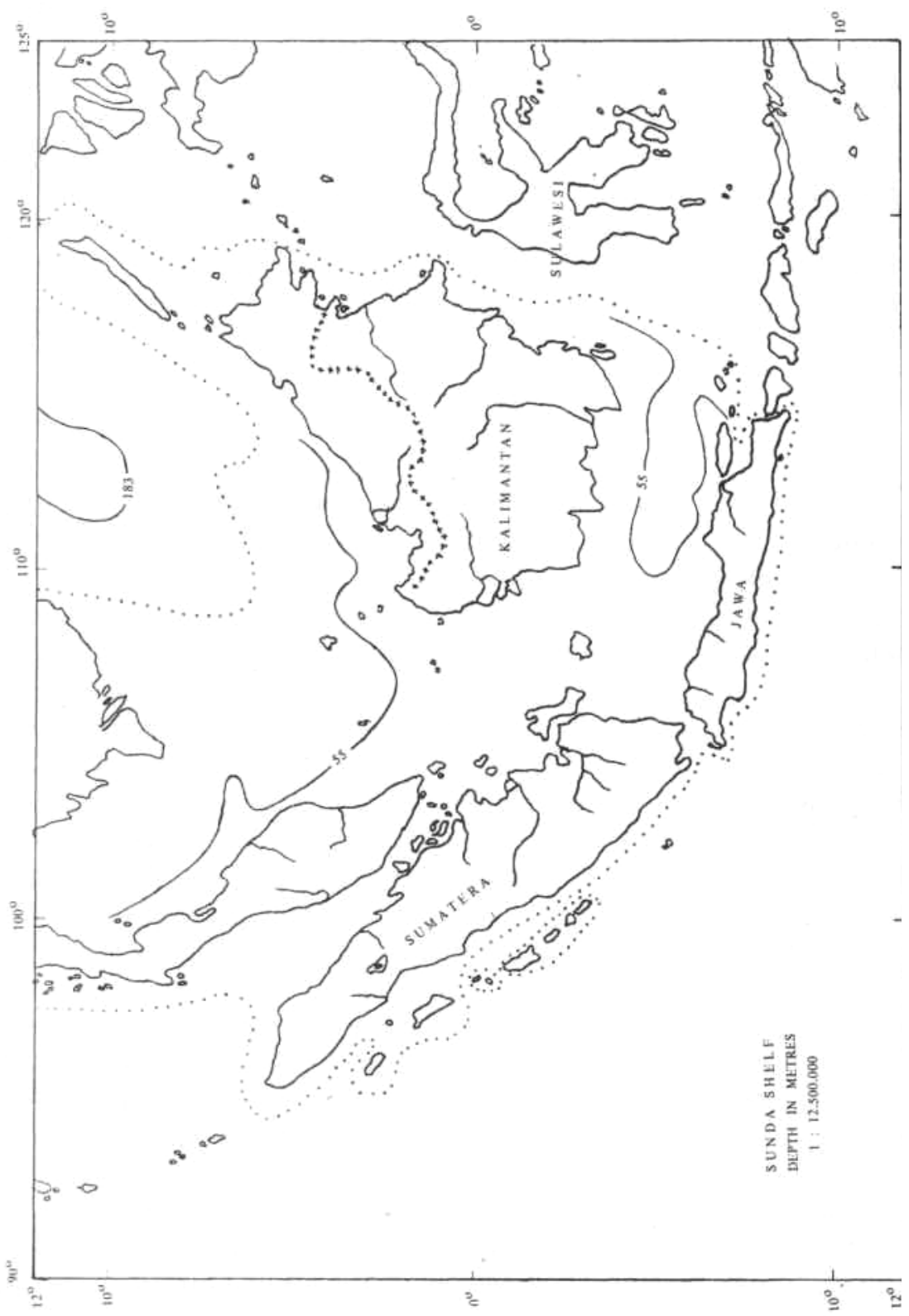




\section{DJAMHIR PARDJAMAN}

Sea conditions of the area are directly related to the monsoon. The NWmonsoon winds are stronger than those of the SE-monsoon, so that maximum sea and swell in this area occur during the NW-monsoon.

Investigations during the mentioned hydrographic surveys were carried out within latitudes $10^{\circ} 00^{\prime} 00^{\prime \prime} \mathrm{N}$ to $10^{\circ} 00^{\prime} 00^{\prime \prime} \mathrm{S}$ and longitudes $95^{\circ} 00^{\prime} 00^{\prime \prime} \mathrm{E}$ to $120^{\circ} 00^{\prime} 00^{\prime \prime} \mathrm{E}$ with special references to the waters of the east coast of Sumatera (Belawan, Dumai, Rupat), west coast of Kalimantan (Padang Tikar) and the north coast of Jawa including Bali (Jakarta Bay/SebaruPabelokan, Cirebon, Indramayu, Celukan Bawang, and Amuk Bay) - See Lists of References attached, page 10.

\section{RESULTS}

Information in the coastal morphology, obtained during the mentioned hydrographic surveys, and the estuary characteristics seen in the local environmental conditions are as follows:

a) Belawan: the type of vegetation along the coastline generally consists of mangrove, whilst only a spot of pine trees was found. Several parts of the coastline near Beting Camar have changed due to wave erosion. At several places along the river mouth of the Deli River, the coastline has also changed as a result of silting.

Dumai and Rupat: the coast is solely covered by mangrove swamps. It is still extremely difficult to reach the shore from the sea even during low tide. Fish traps and fish stakes were scattered through the area. Padang Tikar (West coast of Kalimantan): Some parts of the coast are covered by mangrove swamps, while the rest is mainly covered by nipah (Nypa fruticans).

Coast of Jawa: at Sebaru-Pabelokan, the type of flora along the coastline generally consists of coconut trees and other vegetation, including mangrove. Along the coast of Indramayu and Cirebon, mangrove swamps were found sparsely, as well as rice fields, vegetation and fish ponds. Mud flats could be seen during ebb tide. Fish traps and fish stakes were also found covering the shallow parts of the coast. Bali: at Celukan Bawang and Amuk Bay, the condition of the coast are different than the areas mentioned before. Coconut trees are found along the coast, on the other hand corally because stretched out to the sea.

b) Based on the observation on tide and tidal currents, it was found that 


\section{SOME NOTES OF THE HYDROGRAPHIC SURVEY}

the type of tide in these survey areas differed from one place to another due to geographical and local conditions. The type of tide observed in Belawan and Dumai is semidiurnal with a range up to $2 \mathrm{~m}$ until $2.50 \mathrm{~m}$. In Padang Tikar, it is of diurnal type with a range up to $2 \mathrm{~m}$ and more. In Indramayu, Cirebon and Bali (Celukan Bawang and Amuk Bay) the type of tide is of mixed semidiurnal with a range up to $1.25 \mathrm{~m}$ until $1.50 \mathrm{~m}$.

The deformation of the tidal wave in shoal areas and/or the encounter of the tidal wave with the river current, opposing each other, caused a time difference of the high waters, especially in the channel and harbour (e.g. in Belawan).

c) The result of current observations is as follows:

\begin{tabular}{l|c|c|c}
\hline \multirow{2}{*}{ Name of Place } & \multicolumn{2}{|c|}{ Current Velocity } & \multirow{2}{*}{ (knot) } \\
\cline { 2 - 3 } & Ebb & Flood & NNW \\
\cline { 2 - 3 } Belawan & up to 3.0 & up to 2.0 & SSE \\
& up to 2.3 & NW to 2.3 & SW \\
Padang Tikar & up to 0.2 & up to 1.5 & ESE \\
Sebaru-Pabelokan & up to 0.2 & up to 0.1 & NE \\
Cirebon & up to 0.16 & up to 0.07 & WW \\
Indramayu & up to 0.95 & up to 0.38 & ENE \\
Celukan Bawang & up to 1.2 & up to 0.67 & ESE \\
Amuk Bay & up to 0.51 & up to 0.18 & NE \\
& & SW \\
& & NNW \\
\hline
\end{tabular}

The above figure shows that the current circulation largely depends on the coast formation, the shallow water and also on the monsoonal regime which governs the general flow of the waters in these surveyed areas.

d) Visual observation on waves drew the result which in these survey areas windwaves played a great role while the sea surface was directly influenced by many other factors. The result of the observation is as follows: 


\section{DJAMHIR PARDJAMAN}

\begin{tabular}{|c|c|c|c|}
\hline Name of Place & $\begin{array}{l}\text { Observed wind } \\
\text { velocity (knot) }\end{array}$ & $\begin{array}{l}\text { bserved wave } \\
\text { height (m) }\end{array}$ & $\begin{array}{l}\text { Period of } \\
\text { Observation }\end{array}$ \\
\hline $\begin{array}{l}\text { Belawan Dumai } \\
\text { Sebaru-Pabelokan } \\
\text { Cirebon Indramayu } \\
\text { Amuk Bay }\end{array}$ & $\begin{array}{l}\text { up to } 15 \\
\text { up to } 20 \\
\text { up to } 20 \\
\text { up to } 25 \\
\text { up to } 17 \\
\text { up to } 16\end{array}$ & $\begin{array}{l}\text { up to } 0.70 \\
\text { up to } 0.80 \\
\text { up to } 1.20 \\
\text { up to } 1.25 \\
\text { up to } 0.20 \\
\text { up to } 0.50\end{array}$ & $\begin{array}{l}\text { July - September June - } \\
\text { August October - } \\
\text { November May } \\
\text { November - December } \\
\text { December }\end{array}$ \\
\hline
\end{tabular}

e) Bottom characteristics of the surveyed areas, were determined from underway-samples and partly from the echotracers on the recording papers.

Belawan is situated between two river mouths, the Belawan and Deli River, which directly influence the water circulation in the harbour and start a shoaling process. The bottom consists mostly of fine sand and muddy sand.

In Dumai the bottom consists mostly of grey mud, sand and gravel, shingly sand and clay. In Cirebon and Indramayu the bottom was covered with mud and sand, while in Sebaru-Pabelokan, Celukan Bawang and Amuk Bay the nature of the bottom was coral or corally sand and stony substance. 
f) The weather mean results during the observations could be described as follows:

\begin{tabular}{|c|c|c|c|c|c|}
\hline Name of Place & $\begin{array}{l}\text { Wind speed/main } \\
\text { direction }\end{array}$ & $\begin{array}{l}\text { Rainfall } \\
\text { during period } \\
\text { of observation }\end{array}$ & $\begin{array}{l}\text { Daily max. } \\
\text { average air } \\
\text { temperature }\end{array}$ & $\begin{array}{c}\text { Daily min. } \\
\text { average air } \\
\text { temperature }\end{array}$ & Period of observation \\
\hline Belawan & 06-16 knots/NNE & up to $12 \mathrm{~mm}$ & $29.4^{\circ} \mathrm{C}$ & $24.0^{\circ} \mathrm{C}$ & June -October 1969 \\
\hline Dumai & $\begin{array}{l}\text { 07-10 knots/ESE } \\
03 \text { 08 knots/SE-SW }\end{array}$ & $\begin{array}{l}\text { up to } 199 \mathrm{~mm} \\
\text { up to } 55 \mathrm{~mm}\end{array}$ & $29.8^{\circ} \mathrm{C}$ & $22.8^{\circ} \mathrm{C}$ & $\begin{array}{l}\text { October } 1968 \\
\text { November } 1974\end{array}$ \\
\hline Rupat & 07-15 knots/E & up to $150 \mathrm{~mm}$ & $32.0^{\circ} \mathrm{C}$ & $24.3^{\circ} \mathrm{C}$ & January - March 1974 \\
\hline Indramayu & 15 knots/SW-NW & up to $200 \mathrm{~mm}$ & $30.1^{\circ} \mathrm{C}$ & $24.6^{\circ} \mathrm{C}$ & November 1969 - February 1970 \\
\hline Celukan Bawang & 4-10 knots/N-SW & up to $200 \mathrm{~mm}$ & $31.5^{\circ} \mathrm{C}$ & $24.6^{\circ} \mathrm{C}$ & November - December 1974 \\
\hline Amuk Bay & up to 16 knots/W-SW & up to $304 \mathrm{~mm}$ & $31.0^{\circ} \mathrm{C}$ & $25.0^{\circ} \mathrm{C}$ & December 1974 \\
\hline
\end{tabular}




\section{DJAMHIR PARDJAMAN}

\section{DISCUSSION}

As mentioned above, most of the survey areas were located in estuaries and there for, due to local environmental condition, each area had its own characteristic. At the discussed places, typical examples of estuaries are Belawan, Padang Tikar and Indramayu, because of their locations on embayments of the ocean that are diluted by run off from the land.

It is known that the circulation in an estuary depends on the amount of fresh water discharge, the tidal current, and the amount of vertical mixing. All these factors played an important part in the surveyed areas, although to a different degree in each area.

The average daily minimum air temperature did not fall below $22.0^{\circ} \mathrm{C}$ while the average daily minimum sea water temperature is a little bit higher so that environmental conditions are favourable for the growth of reef and coral building as according to WEYL (1969): "coral exist at all depth within the ocean, however, reef building coral occur only in shallow tropical waters that are brightly illuminated and whose temperature does not fall below $10.0^{\circ} \mathrm{C} . "$

Although coral or corally sand was found every where in the surveyed areas, but Sebaru-Pabelokan, Celukan Bawang and Amuk Bay have the most favourable conditions for reefs, because there was less or no fresh water discharge in these areas compared to the other areas. Obtained data showed that sea water temperature in Celukan Bawang and Amuk Bay during the observations varied between $30^{\circ} \mathrm{C}$ and $32^{\circ} \mathrm{C}$, while the salinity values were between 32\% and 33\%.

Mangrove and other sea vegetation was found along the coast. From one place to another the type of tides and their ranges differed, and these factors played on important role within the tidal zone.

\section{CONCLUSIONS}

Information on the physical, geological, chemical and biological factors that shaped the marine environment, obtained during the hydrographic surveys, could be concluded as follows:

a. Coral reefs are found every where in these relatively shallow areas, whilst in some regions the conditions for reef building are more favourable.

b. The tides and their characteristics play an important role within the tidal zone along the coast. 
c. Most of the surveyed areas are located in estuaries, and thus their characteristics differed from those in the open sea.

d. In general the climate of the areas is governed by the monsoonal regime, as well as the local conditions

\section{ACKNOWLEDGEMENTS}

The author is grateful to all members of the staff and the survey team of "JANHIDROS" for their valuable comments and cooperation in obtaining the data in this paper.

\section{BIBLIOGRAPHY}

DIREKTORAT HIDROGRAFI ANGKATAN LAUT 1968. Report of the Hydro-Oceanographic Survey in Dumai/Riau, June-November 1968. (in Indonesian).

.... 1969. Report of the Hydro-Oceanographic Survey in Belawan/East Sumatera, JuneOctober 1969. (in Indonesian).

..... 1970. Report of the Hydro-Oceanographic Survey in Indramayu, November 1969-February 1970. (in Indonesian).

..... 1970. Report of the Hydro-Oceanographic Survey in Cirebon Harbour, May—June 1970. (in Indonesian).

.....1970. Report of the Hydro-Oceanographic Survey in Sebaru-Pabelokan, OctoberNovember 1970. (in Indonesian).

JAWATAN HIDRO-OSEANOGRAFI ANGKATAN LAUT 1974. Report of the HydroOceanographic Survey in waters of western Kalimantan, June-September 1974. (in Indonesian).

..... 1974. Report of the Hydro-Oceanographic Survey in the waters of Celukan Bawang/Bali, November-December 1974. (in Indonesian).

..... 1974. Report of the 3rd Joint Hydrographic Survey in Malacca-Singapore Straits, 1974.

..... 1974. Report of the Hydro-Oceanographic Survey in Amuk Bay/Bali, December 1974. in Indonesian).

...... 1974. Report of the Hydro-Oceanographic Survey in Rupat and Bengkalis Straits,

January-March 1974. (in Indonesian). _- 1975. Report of the Hydro-Oceanographic Survey in Belawan, January-February 1975. (in Indonesian).

WEYL, P. K. 1969. Oceanography - an introduction to the Marine Environment. John Wiley \& Sons, Inc. New York, London, Sydney, Toronto. 